\title{
The HS Company - Restructuring the Processes and Improving Organizational Excellence: Role of Top Management in Strategic Reorientation
}

\author{
Barbara Czerniachowicz \\ Dr, Department of Enterprises Economics, Institute of Management and \\ Investment, Faculty of Economics and Management, University of Szczecin
}

\section{Introduction}

The aim of this paper is to present the selected aspects of proecological strategic reorientation in the HS Company. The company is a producer of parts for machines used in several industrial sectors of the Polish economy. The HS company is the manufacturer with a more than 100-year-old tradition of offering high-quality products, construction and design, market suppliers, extensive knowledge of gear production, and technological support.

In order to achieve the aim of the article, the following objectives are formulated: (1) presenting the history and characteristics of the HS company; (2) introducing the concepts of strategic reorientation in the HS company; and (3) identifying how the company implemented the approved strategy by using contemporary tools of strategic management.

Nowadays, the HS company is a reliable manufacturer aiming at continuous development and creating opportunities for personal development of its employees. The company attaches great importance to its customers' satisfaction and the newly adopted profile of the HS brand. It also strives to gain the

\section{How to cite this book chapter:}

Czerniachowicz, B. 2019. The HS Company - Restructuring the Processes and Improving Organizational Excellence: Role of Top Management in Strategic Reorientation. In: Gąsior, A. (ed.) Pro-ecological Restructuring of Companies: Case Studies, Pp. 97-107. London: Ubiquity Press. DOI: https://doi.org/10.5334/bbk.h. License: CC-BY 4.0 
appreciation of the local society and all its customers. All the groundbreaking changes were possible due to the strategic reorientation that was started in 2012.

\section{Methodology}

A strategy is a concept of systemic action based on the formulation of a set of long-term goals and their modifications depending on changes in the surrounding business environment. It requires the determination of the resources, the means necessary to achieve these objectives and the procedures for optimal distribution and their use. The aim of such activities is to react flexibly to market challenges and to ensure that the company operates in conditions conducive to its development (Penc 1994; Filipiak-Dylewska \& Szewczuk 2000). The concentration strategy aims to choose a specific market segment - generally a geographically close market - and a consumer or a product type. This strategy is based on the assumption that a company can thus better and more efficiently service its narrow strategic segment of the market than its competitors. Due to such measures, a company is either able to achieve diversification by the effective fulfillment of its segment's needs or to lower the costs of service, or both (Moszkowicz 2005). This strategy is particularly favored by companies with limited production resources, insufficient possibilities for flexible operation or the ones unable to adapt rapidly and effectively to a changing market situation (Stróżycki 1999).

The instruments used to implement the overall strategy of a company can be either functional strategies that focus on how the organization approaches its basic functional activities (Pierścionek 1997) that are prepared for such areas as marketing, finance, manufacturing, research and development, human resources or logistic processes or production strategies relevant to those elements of a company's strategy that influence its manufacturing activity (Griffin 1997; Griffin 2015; Stabryla 2000; Krupski 1999; Urbanowska-Sojkin 1998; Urbanowska-Sojkin 2011). This strategy focuses on the quality, performance and technology and it is an integral part of the marketing strategy and a company's human resources. Due to the fact that it is dependent on the aforementioned factors, it is often very difficult to be distinguished from others and thus it is contractual in nature. The decisions included in the production strategy generally relate to issues included in the overall strategy, focusing, however, on their operational details (Filipiak-Dylewska \& Szewczuk 2000; Kaleta 2010). Changes in the production strategy influence the reorientation of other functional strategies of a company (Krajewski 2009; Kaczmarek et al. 2005).

The presented case study carried out on the HS company in 2012 discusses the strategic reorientation associated with the necessity of introducing changes allowing the company to adapt to the changes in the environment. The restructuring mainly focused on the areas of production, employment, logistics and 
marketing (Czerkas \& Teisseyre 2016; de Sousa 2014). The changes in functional strategies implemented from the years 2012 to 2015 aimed at improving organizational excellence (Recardo \& Heather 2013; Crooks 2012).

The analyses were carried out on the basis of the original source material collected from the entities belonging to the HS company. The study used detailed, in-depth personal interviews, expert interviews, observations and the author's own survey. The scope and the depth of the study faced serious difficulties due to the inaccessibility of reliable data and problems with interviewing a sufficient number of employees. Independent observations, direct measurements and in-depth group and personal interviews were conducted in the period between 2012 and 2015 .

\section{History and Characteristics of the HS Company}

The HS Sp. z o.o. (limited liability company) was founded in 1905 by a master of casting and operated as a family business. After the Second World War it was nationalized. Since its inception, the company prospered on the market very well. However, beginning in the early 1980s, it produced worse financial results, and the collapse of the Russian market resulted in the most difficult period for the company. In 1993, the company acquired a strategic investor to recapitalize the company, thus giving it a chance to gain new markets for manufactured gears and to expand the production of new products. On 4 December 1997, the Sipma S.A. (Holding) became the owner of $70 \%$ of the shares in a tender. Internal restructuring was carried out, redundant assets sold and agreements with creditors signed, which allowed the company to repay its debts. On 28 December 2010, Sipma Company sold all its shares to Grupa Kapitałowa Complex (Complex Holding), which has since become the main shareholder of the company.

The company had 42 shareholders. The share capital of the HS company amounted to $2,118,750$ zlotys, which covered a total of 41,965 shares with a nominal value of 50 zlotys per share.

The organization constantly expands the product offer for its customers, along with technical advice. The company specializes in hydrodynamic transmissions, brake pumps for construction, road and mining and angular and cylindrical gears, as well as in hydraulic cylinders for agricultural machinery.

A constantly modernized machine park with proecological sozotechnical devices and experienced staff allow the company to take on new challenges related to production and services and to cooperate with partners in accordance with the wishes of domestic and foreign customers. Experience in the industry, a unique high-quality offer and availability of individual components, subassemblies and complex hydraulics and transmission, allow the company to be a key partner for demanding customers, all the while preparing a sales program to meet the needs of its customers in all industries. 
The company's mission is to create and deliver comprehensive, innovative and systemic solutions for power transmission and energy. Their promoted values are associated with honesty (related to integrity), customer satisfaction, reactivity and continuous improvement.

Top managers realize proecological goals through the implementation of the following principles:

- ensuring continuing suitability, adequacy and effectiveness of the Quality Management System

- constant monitoring of customer satisfaction and taking actions to increase satisfaction

- constant tracking and application of the current legal requirements, standards, trends and technological progress

- systematic workers' qualifications deepening their awareness of their role and responsibility in meeting customers' requirements, legal requirements and standards

- maintaining a constant satisfaction of all the stakeholders of the organization

- conducting business in a manner friendly to the environment and health and safety at work

\section{Management in the HS Company and Strategic Reorientation}

In 2012, the HS Company experienced a crisis caused by a significant reduction in orders from the largest client - Sipma Holding. Discussions with the top management of SIPMA revealed that the crisis was expected to last for two quarters of 2012. Sipma had a number of orders from the Eastern European market that ceased to come and the company was forced to seek new customers. Similar events had occurred in the past; thus the company limited its production in order to last for the period. But for the HS Company, the situation was serious and required a huge effort on the part of the management and employees of the company in order to survive and look for new customers.

Sales potential was insufficient for a given mode of operation. Employees had extensive knowledge and experience in their field, but their effectiveness to attract new orders was limited. Therefore, the managers hired young workers to take advantage of the synergy of youth and experience in order to stimulate proper dynamics of the sales department (Karaszewski \& Lis 2013).

Revenues from new orders were clearly too small, and there was no chance for an increase without financial support in order to change the manner and methods of sales department activity. The top management planned to use the crisis to "clean up" the company's problems and achieve higher revenue.

A big challenge for managers was to transform the organization into a profitable company. It was also a very costly operation due to redundancy payments, among other things. Organizational measures taken in May 2012 and 
consistent implementation of new solutions brought positive financial results in October 2012. In subsequent years, Sipma Holding, as the biggest client, increased orders for products from the HS company, which positively influenced the improvement of financial results of the company.

The main goal of the recovery program was to re-establish a profitable financial position of the company through cost cutting. In the opinion of the managerial staff, the difficult situation was temporary; thus they planned employment restructuring, cost reduction, change in working methods of the sales and production departments, and other organizational units.

The process of transformation was very expensive, and the workers were resistant as it forced them to work harder in order to improve the situation of the company. From May 2012 the lay-offs began, and this had a negative impact on the atmosphere and organizational culture.

HS Company focused on reducing operating costs, while maintaining a strong market position of angular gears and hydraulic systems. The company had fewer clients than before because it was now in a specialized market.

In 2012 the managers adopted a new strategy, which had to be verified due to the crisis. Its redefined assumptions were as follows:

1. adjustment of employment to the optimum level of capacity of production and the structure of realized sales

2. reducing costs, shortening lead times, optimum utilization of the machine park

3. verifying all agreements concluded by HS at lower prices used and determining reasonableness of their further continuation and reducing the operating costs of the company

4. increasing productivity and efficiency

5. increasing the level of services and manufactured goods

6. activation of new markets

7. modification of the machinery for proecological and efficient execution of orders

HS clarified its strategic advantage that was based on a more than 100-year-old tradition of offering products for several industrial sectors, high-quality products, extensive knowledge of gear production, market suppliers, customers and technological support, construction and design.

The managers also formulated product strategies focusing on market and product development strategy and market penetration strategy. They clarified the strategic product groups. Strategy for market and product development was related to the desire to become the leader among producers. The measures taken to achieve this aim included an increase in sales of existing products and offering new or improved products for existing and newly acquired markets. The main objectives of this strategy were: 
- quality improvement;

- shortening lead times within the Customer Relationship Management (CRM); and

- reducing purchasing cost of materials by $10 \%$.

The market penetration strategy was associated with an increase in the market share due to intensified sales activities, promotion and acquisition of new distribution channels.

Strategic objectives for the year 2012 were:

- generating net profit of 500,000 zlotys.

- increasing sales by $21 \%$.

The main objectives for the sales and marketing department that year were:

- achieving total sales of 14 million zlotys (in Poland - 12 million zlotys, a $16 \%$ increase; abroad - 2 million zlotys, a 100\% increase).

- acquiring at least two new customers (expected total turnover next year of at least 4 million zlotys).

For the long-term, the following goals were pursued:

1. creating tools enabling comprehensive customer service, primarily through expanding the product range, mainly thanks to the cooperation with Chinese companies;

2. acquiring new customer segments; and

3. introducing new products of unique technical solutions.

As part of the marketing strategy the managers assumed, among others, modernization of the graphic image of the brand, supporting direct sales with a series of gadgets with the company logo, using the Internet to reach a wider group of customers, positioning pages and web banners on industry-specific portals, and raising standards of packaging to the level of market leaders.

Changes in the sales promotion were mainly focused on creating a modern Internet platform (i.e. and online store offering delivery of products in 48 hours) and the introduction of loyalty programs for regular customers. The changes entailed the introduction and promotion of new products - preceded by market research and a demand forecast - preparation of promotional materials and a database of potential clients, and the launch of information and promotional campaign before the introduction of products into the market.

In determining the strategy for customer service, the managers of the company considered increasing the sales force productivity to be the most important issue. Thus, the country was divided into three sales regions, whilst the foreign 
or external market was divided into two regions (close to the customer). The company hired new regional sales managers and provided them with the tools necessary for fieldwork (i.e. a company car with a GPS, mobile phone, marketing tools). It also developed and implemented a training system for the sales department and introduced high labor standards based on a control-incentive system of Customer Relationship Management (CRM).

Orders were processed and fulfilled according to higher standards than those of domestic and foreign competition. The total delivery time was reduced to the best level in the industry, all the while maintaining quality standards. The company reduced the time associated with offering and preparing orders for production - the development of CRM (e.g. an efficient information-flow system between clients and the HS company, checking inventory online, offering standard products within several minutes, the process of completion of orders for standard products, issuing a manufacturing order within one hour).

Professional presales service for the HS clients related to technical advice on the selection of products, home demonstrations and customer training on the preparation and the proper use of products offered by the company. The professional service provided by the sales department was associated with after-sales service based on managing complaints and organizing technical training of managers and sales representatives. The strategy of customer service also included the development of distribution channels, both indirect distribution (boosting the sales and improving the quality of service by the managers and sellers and developing the sales network on foreign markets), as well as direct distribution to manufacturers with a focus on increasing sales of new products, through professional advisory services and an individual approach to customers and the launch of an online store. The company also introduced a system of foreign customer service.

The production strategy focused on joining the three production departments into one called Jotes Business Park. The main aim was to ensure that the production took place at a lowest cost, while maintaining the quality of products and punctuality in fulfiling orders to increase competitiveness on the market and achieve a high sales margin. The activities planned and implemented by the management in this area included:

- reorganizing production in order to reduce the cost of manufactured products and increase proecology;

- reducing production costs by $15 \%$ for each of the three production departments;

- increasing productivity by $20 \%$;

- shortening production time by $20 \%$;

- increasing production capacity while reducing the machinery park by $40 \%$;

- eliminating mismanagement and preparing weekly reports and calculations;

- achieving competitive advantage; and

- creating a modern and international image of the company. 
The tasks of the production strategy were carried out through the creation and implementation of a plan for relocating machinery, equipment and technology among the three departments and implementation of ecological solutions on production. The level of quality meeting the needs of target markets was maintained, and the production of orders was quicker and timely. The management also introduced production services and implemented procedures for Quality Management System ISO 9001 for the joint production plants. The company increased production capacity through the introduction of new production technologies and aimed to cooperate with the Technical University (University of Łódź) to pursue research and development activities and increase production.

In the logistics department, the managers strove to ensure timely deliveries and reduce purchasing costs, working time of warehouses, labor costs, stock levels and the cost of storage, the amount of complaints due to poor quality of purchased materials and poor work organization of the purchasing department.

The managers primarily introduced indicators to check and verify timeliness of completed deliveries, late deliveries or advertised deliveries, and to assess the efficiency of delivery, the loss of production due to lack of supply, productivity and operating efficiency. Within these tasks, the company also created a bonus system based on the indicators, introduced new solutions for supplying materials and raw materials to the company. It partnered with new shipping companies and providers of supplies necessary for the production of materials and semi-finished products, thereby reducing purchasing costs. The company changed the way it purchased materials, i.e.:

- the purchasing department bought smaller batches of materials.

- deliveries were divided proportionally to the demand sufficient to maintain production.

- the company renegotiated the minimum levels of purchase or signing contracts favorable to the company.

- the company used suppliers' warehouses to store materials.

The expected results came very quickly and were mainly noticeable in the more efficient management of human resources due to the ability to monitor the work of people allowing the company to make instant adjustments necessary to maintain production. Another result was the reduction of costs associated with delegating workers to the current material supply, reducing costs of storage and costs of leasing other transport companies on Polish territory (Gąsior 2015).

Reducing the working time of warehouses resulted in limiting overtime and other related costs and shortening working time of warehouse workers when giving out components for installation on the production line. Other benefits included shortening the time spent searching for parts and providing better quality of service both for internal and external customers by reducing the number of mistakes. 
Reducing labor costs was mainly based on the implementation of the Kanban system in terms of shopping queues, inventory and the occupied space. The company also established close cooperation with the production department in order to develop a production plan for meeting deadlines. Another important element of the strategy was the continuous improvement of the $5 \mathrm{~S}$ system together with the Lean Manager. The results of these activities were on-time availability of the necessary tools ensuring the continuity of production; simultaneous reduction of the need for machinery refitting caused by the lack of materials, thus shortening the time of making job lot; the possibility of better control over employee working time; and increasing the income of the company by selling redundant items, stock and scrapping obsolete tools, which resulted in reducing the occupied space by $36 \%$.

The task posed by the management aiming to reduce inventory and storage costs was based on selling products in stock for more than six months and excluding costs of cutting process of materials from inventory costs. The close cooperation between the purchasing and sales departments and a good flow of information on suppliers in order to sell surplus stock were important here. The expected results came very quickly and in subsequent years resulted in the reduction of inventory, warehouse space and in a better control of inventory and warehouse costs.

The managers took up the challenge to reduce the amount of complaints due to poor quality of purchased materials. For this purpose, they made a ranking list of suppliers, dividing them into categories of materials, on the basis of a list of materials requiring qualification and a register of current and potential suppliers. The company also prepared a register of current and potential suppliers and the purchasing department defined a quality indicator of suppliers. These measures reduced the number of complaints arising from poor quality of parts fitted to the products. At the same time, the company improved the quality of products and acquired new clients, which had a positive impact on its image.

\section{Conclusion}

The difficult market situation in 2012 forced the managers of the HS company to implement proecological strategic reorientation. The managers introduced a number of changes and modifications in the organization and its functioning. The employment restructuring required funds for redundancy payments for employees laid off for economic reasons.

The managerial staff also changed the organization of production in order to reduce the costs of manufactured products. The company created a new organizational structure for the joint production department and introduced new management methods. The company also defined competence matrix for its employees and developed a training program for production workers. 
Additionally, the managers applied the just-in-time and Lean Manufacturing concepts, the analyses and statistical methods for production and set targets for specific processes. As for the logistics department, they reduced the costs of logistic processes by $20 \%$ in 2012 compared to 2011 . In subsequent years, the company still strove to reduce these costs. The managers eliminated all inefficient operations and activities and introduced restructuring that allowed them to improve the functioning of the entire organization. Constant improvement and organizational changes have since become the main strategic objective of the HS company.

\section{References}

Crooks, S 2012 Managing a successful organisation restructure. Available at https://www.plushr.com/plushr-performance-management-roundtabledec-2012/ [Last accessed 10 October 2016].

Czerkas, K and Teisseyre, B 2016 Restrukturyzacja zadłużenia przedsiębiorstw. Od ugód bilateralnych do postępowań restrukturyzacyjnych i upadłościowych, Ośrodek Doradztwa i Doskonalenia Kadr Sp. z o.o., Gdańsk.

de Sousa, J 2014 Organizational restructuring and change management using a neuroscientific approach. Available at https://www.linkedin. com/pulse/20140810231843-2117408-organizational-restructuringand-change-management-using-a-neuroscientific-approach [Last accessed 15 November 2016].

Filipiak-Dylewska, B and Szewczuk, A 2000 Zarządzanie strategiczne, Fundacja na rzecz Uniwersytetu Szczecińskiego, Szczecin.

Gąsior, A 2015 Salaries as a Determinant of Restructuring Large Companies in Poland. Transformations in Business \& Economics, 14(3C)(36C): p. 389-406.

Griffin, R W 2015 Podstawy zarządzania organizacjami, PWN, Warszawa.

Griffin, R W 1997 Podstawy zarządzania organizacjami, PWN, Warszawa. p. 256.

Kaczmarek, J, Krzemiński, P, Litwa, P, and Szymla, W 2005 Procesy zmian w okresie transformacji systemowej. Prywatyzacja, restrukturyzacja, rynek kapitałowy, Wydawnictwo Akademii Ekonomicznej w Krakowie, Kraków.

Kaleta, A 2010 Dylematy wyboru strategicznego współczesnych przedsiębiorstw, in: Zarządzanie współczesnymi przedsiębiorstwami. Uwarunkowania strategiczne, innowacyjne i kulturowe, ed. T. Falencikowski, WSB, Gdańsk. pp. 37-49.

Karaszewski, R and Lis, A 2013 The Role of Leadership to Stimulate Pro-developmental Positive Organisational Potential, In: Stankiewicz, M J (ed.) Positive Management: Managing the Key Areas of Positive Organisational Potential for Company Success. , Dom Organizatora TNOiK: Toruń. pp. 59-87. 
Krajewski, S 2009 Prywatyzacja, restrukturyzacja, konkurencyjność polskich przedsiębiorstw, PWE, Warszawa.

Krupski, R (ed.) 1999 Zarządzanie strategiczne, Akademia Ekonomiczna, Wrocław. p. 207.

Moszkowicz, M (ed.) 2005 Zarządzanie strategiczne. Systemowa koncepcja biznesu, PWE, Warszawa. pp. 137-161.

Penc, J 1994 Strategie zarządzania, Perspektywiczne myślenie - systemowe działanie, AW Placet, Warszawa. pp. 142-143.

Pierścionek, Z 1997 Strategie rozwoju firmy, PWN, Warszawa. p 185.

Recardo, J R and Heather, K 2013 Ten best practices for restructuring the organization. Global Business and Organizational Excellence. January/February. Pp. 23-37. DOI: https://dx.doi.org/10.1002/joe.21470.

Stabryła, A 2000 Zarządzanie strategiczne w teorii i praktyce firmy, PWN, Warszawa-Kraków. p. 69.

Stróżycki, M (ed.), 1999 Podstawy zarządzania przedsiębiorstwem. Szkoła Główna Handlowa, Warszawa. p 169.

Urbanowska-Sojkin, E 1998 Zarządzanie przedsiębiorstwem, AE, Poznań. p. 149.

Urbanowska-Sojkin, E (ed.) 2011 Podstawy wyborów strategicznych w przedsiębiorstwach, PWE, Warszawa. 
